\title{
KEARIFAN TRADISIONAL DALAM PENGELOLAAN SUMBER DAYA PERIKANAN DI ACEH PADA ERA OTONOMI KHUSUS
}

\author{
Sulaiman \\ Fakultas Hukum Universitas Syiah Kuala \\ E-mail: st_aceh@yahoo.co.id
}

\begin{abstract}
Reformation in Indonesia give implication for Aceh, which is the authority in the form of implementation of fisheries management based on traditional wisdom. Those statement above are trying to answer the question of this traditional wisdom in the era of special autonomy. The important finding is critical condition of fisheries resources which is caused by a disregard pattern of traditional management wisdom. It is recommended that policy makers doing holistic approach to fisheries management.
\end{abstract}

Keywords: Fishing, Traditional Wisdom, Aceh

\begin{abstract}
Abstrak
Reformasi di Indonesia turut berimplikasi bagi Aceh, yakni kewenangan pelaksanaan pengelolaan perikanan berdasarkan kearifan tradisional. Paparan ini menjawab persoalan kearifan tradisional pada era otonomi khusus. Temuan pentingnya adalah kondisi kritis sumberdaya perikanan, turut disebabkan pola pengelolaan yang mengenyampingkan kearifan tradisional. Direkomendasikan agar pengambil kebijakan melakukan pendekatan holistik dalam pengelolaan perikanan.
\end{abstract}

Kata Kunci: Perikanan, Kearifan Tradisional, Aceh

\section{Pendahuluan}

Proses reformasi yang berlangsung di Indonesia tahun 1998, menjadi momentum penting bagi lahirnya otonomi daerah di Indonesia. Terjadinya reformasi menyebabkan terbukanya kran demokratisasi dalam masyarakat. Dengan adanya reformasi yang memungkinkan lahirnya Undang-Undang Nomor 22 Tahun 1999 tentang Pemerintahan di Daerah. Undang-undang tersebut yang memungkinkan berbagai kearifan tradisional memungkinkan untuk dilaksanakan. Lahirnya Undang-Undang Nomor 22 Tahun 1999 telah memberikan kewenangan yang lebih luas bagi daerah dalam pengelolaan perikanan daIam wilayah Negara Kesatuan Republik Indonesia. ${ }^{1}$

\footnotetext{
Sulaiman, 2010, Konsep Pengelolaan Sumberdaya Perikanan Berbasis Kearifan Lokal Di Aceh Pada Masa Otonomi Daerah, Makalah Lokakarya 8 Tahun Otonomi Daerah, Malang: Universitas Brawijaya, hlm. 2.
}

Kewenangan daerah yang lebih luas yang diatur dalam Undang-Undang Nomor 22 Tahun 1999, adalah bentuk terbukanya kran dari desentralisasi yang mulai berlangsung di Indonesia. Hal ini tercermin dari filosofi lahirnya Undang-Undang Nomor 22 Tahun 1999, yakni: pertama, sistem pemerintahan Negara Kesatuan Republik Indonesia menurut Undang-Undang Dasar 1945 memberikan keleluasaan kepada Daerah untuk menyelenggarakan Otonomi Daerah; kedua, penyelenggaraan Otonomi Daerah tidak bisa dipisahkan prinsip-prinsip demokrasi, peran serta masyarakat, pemerataan dan keadilan, serta potensi dan keanekaragaman Daerah; ketiga, Otonomi Daerah tidak bisa dipisahkan dari perkembangan keadaan, baik di dalam maupun di luar negeri, serta tantangan persaingan global.

Undang-Undang Nomor 22 Tahun 1999 juga telah masuk dalam hal kondisi keberagaman yang ada di daerah-daerah. Bagi Aceh, kenyata- 
an ini dikonkritkan dengan lahirnya Undang-Undang Nomor 44 Tahun 1999 tentang Penyelenggaraan Keistimewaan Aceh. Dalam Undang-Undang tersebut ditegaskan mengenai kewenangan daerah dalam mengatur dan mengembangkan penyelenggaraan keistimewaan yang meliputi agama, adat, pendidikan, dan peran ulama dalam pengambilan kebijakan.

Dua undang-undang tersebut, menjadi dasar kewenangan yang cukup penting dalam hal pengelolaan perikanan berbasis kearifan tradisional. Dengan demikian, kearifan tradisional yang dalam masyarakat tertentu menjadi bagian penting dalam pengelolaan perikanan, adalah bagian tak terpisahkan dari semangat pelimpahan kewenangan pengelolaan perikanan itu sendiri.

Bagi Aceh sendiri lahir Undang-Undang Nomor 18 Tahun 2001 tentang Otonomi Khusus Nanggroe Aceh Darussalam, kemudian UndangUndang Nomor 11 Tahun 2006 tentang Pemerintahan Aceh. Undang-Undang Pemerintahan Aceh mempertegas kewenangan Aceh dalam hal pengelolaan perikanan. Pertama, kewenangan mengelola sumberdaya alam yang hidup di laut Aceh. Kedua, secara eksplisit menyebut kewenangan pemeliharaan hukum adat laut, sebagai bagian penting dari konsep kearifan lokal yang hidup dan berkembang dalam masyarakat pesisir Aceh. Dalam hal ini, kemudian ditegaskan dalam Qanun Nomor 7 Tahun 2010 tentang Perikanan, yang menyebutkan bahwa dalam pengeIolaan perikanan di Aceh memperhatikan hukum adat laut.

Namun demikian dalam era otonomi khusus tersebut, dunia dihantui oleh kondisi perikanan Aceh yang kritis. Dengan potensi perikanan tangkap 127 ribu ton pertahun, sekarang ini Samudra Hindia (pantai Barat) menunjukkan tanda-tanda overfishing, sedangkan Selat Malaka (pantai Timur) telah over fishing sejak tahun 2001. Kondisi ini dapat menurunkan produktivitas ikan dan hasil tangkapan laut, serta perilaku destuktif serta illegal fishing mengancam populasi ikan sehingga jumlah dan ukuran ikan hasil tangkapan menurun. Sebagai perbandingan, 15 jenis ikan dominan pada 1989, pada
1998 menurun menjadi 13, kemudian terus menurun menjadi 9 jenis. ${ }^{2}$

Secara umum, gejala tersebut juga tampak mengglobal. United Nation for Food and Agriculture menyebutkan kondisi perikanan dunia saat ini terbagi dalam tiga kondisi, yakni setengah dari persediaan ikan laut telah sepenuhnya dieksploitasi, seperempat bagian telah dieksploitasi secara berlebihan, dan sekarang ini hanya seperempat bagian saja yang masih tersisa. Seperempat bagian yang tersisa tersebut juga ada di Aceh. ${ }^{3}$ Dengan pola pemanfaatan sumber daya perikanan di Aceh sebagaimana disebutkan di atas, maka di Aceh sekalipun sudah tampak kondisi kritis yang seyogianya mesti segera dicarikan solusinya. Hal ini sangat penting bagi masa depan perikanan Aceh itu sendiri. ${ }^{4}$

Kondisi kritis tersebut, tidak terjadi dengan sendirinya. Kondisi kritis tersebut terkait dengan pola pengelolaan perikanan yang diterapkan. Indonesia termasuk dalam salah satu negara yang di awal tahun 1970-an menggunakan pola memosisikan pembangunan sematamata diorientasikan untuk meraih pertumbuhan ekonomi. ${ }^{5}$ Pola ini dominan digunakan negara di dunia yang penguasaan dan pengelolaan sumberdaya didominasi oleh negara hanya mengejar pertumbuhan ekonomi semata. Di sisi lain, dalam masyarakat lokal umumnya memiliki kearifan lingkungan. Eugen Ehrligh - pelopor sociological jurisprudence - menyebutnya sebagai hukum yang hidup dalam masyarakat (living law).

Tarik-menarik antara kepentingan ekonomi dan sosial budaya di negara ini, kentara terjadi. Di satu pihak daerah memiliki kewenangan mengelola sumberdaya sekaligus kewenangan

2 Razali AR, 2009, Profil Perikanan Tangkap Aceh, Banda Aceh: Dinas Kelautan dan Perikanan Aceh, hlm. 5.

John Kurien, 2009, Suara Panglima Laot, Banda Aceh: FAO, hlm. 4.

4 Sulaiman, "Model Pengelolaan Perikanan Berbasis Hukum Adat Laot Di Lhok Rigaih Kabupaten Aceh J aya", J urnal Masalah-masalah Hukum Undip No. 71 Maret 2011, hlm. 79.

5 I. Nyoman Nurjaya, "Kearifan Lokal dan Pengelolaan Sumberdaya Alam", J urnal IImiah VIII (40) tahun 2007, http:// www.akhirnyaterbitjuga.com, diakses tanggal 30 November 2010. 
menjalankan hukum adat laut, di sisi lain konsep kearifan lokal yang disebut dengan hukum adat laut selalu tidak bisa berdaya di tengah konsep pemanfaatan sumberdaya daya yang hanya berorientasi pada ekonomi semata. ${ }^{7} \mathrm{~Pa}$ dahal pola kearifan lokal umumnya menempatkan kapasitas budaya, sistem pengetahuan dan teknologi, religi, tradisi, dan modal sosial (etika dan kearifan lingkungan, norma-norma dan institusi hukum) sebagai sesuatu yang penting dalam rangka memanfaatkan sumberdaya. ${ }^{8}$ Kapasitas budaya tersebut yang digunakan untuk menyeimbangkan antara pemanfaatkan dan penangkapan dan potensi yang diperkirakan. Konsep tersebut sebenarnya tujuan keberlanjutan dan kelestarian sebagai pertimbangan penting masyarakat lokal dalam memanfaatkan sumberdaya. Konsep dimana pembangunan tidak boleh hanya diorientasikan untuk sekedar mengejar target/rate/kuantitas pertumbuhan ekonomi, dengan mengabaikan dimensi prosesnya. ${ }^{10}$ Berdasarkan latar belakang tersebut, tulisan ini ingin menelusuri pola kearifan lokal dalam pengelolaan perikanan di Aceh, perkembangan pelaksanaannya, serta konsep kearifan tradisional dalam pengelolaan perikanan yang bisa digunakan sebagai konsep bagi masyarakat lainnya

\section{Pembahasan \\ Kearifan Tradisional di Laut Aceh}

Kearifan lokal dalam konsepnya merupakan semua bentuk pengetahuan, keyakinan, pemahaman atau wawasan serta adat kebiasaan atau etika yang menuntun perilaku manusia dalam kehidupan di dalam komunitas ekologisnya. Menurut Nurjaya, kearifan tradisional berpangkal pada sistem nilai dan religi yang dianut dalam komunitasnya. ${ }^{12}$ Ajaran agama dan kepercayaan masyarakat lokal menjiwai dan

6 Sulaiman, "Pelaksanaan Hukom Adat Laot dalam Pengelolaan Perikanan di Aceh", J urnal Mondial IImuIlmu Sosial Dan Kemasyarakatan 11 (19) Januari-J uni 2009, Universitas Syiah Kuala Aceh, hlm. 46.

7 I. Nyoman Nurjaya, VIII (40) tahun 2007, op. cit.

8 I Nyoman Nurjaya, "Pembangunan Hukum Negara dalam Masyarakat Multikultural, Perspektif Hukum Progresif", J urnal Hukum Progresif 3 (2) Oktober 2007, PDIH UNDIP, hIm. 13.

11 I. Nyoman Nurj aya, op. cit. memberi warna serta mempengaruhi citra lingkungannya dalam wujud sikap dan perilaku terhadaap lingkungannya. Hakikat yang terkandung di dalamnya adalah memberi tuntunan kepada manusia untuk berperilaku yang serasi dan selaras dengan irama alam semesta, sehingga tercipta keseimbangan hubungan antara manusia dengan alam lingkungannya.

Kearifan tradisional ditemui dalam masyarakat hukom adat laot di Aceh. Tatanan ini ditemui dalam 147 Lhok di seluruh Aceh. Dalam kaitan ini, Ihok adalah sebuah batasan wilayah kuala atau teluk. J umlah 147 Lhok tersebut terletak di 17 Kabupaten/Kota dari 22 Kabupaten/ kota di Aceh. Kearifan tersebut sudah terbagi ke dalam ketentuan adat yang umum, dan yang berlaku secara spesifik. Ketentuan adat yang umum disepakati di seluruh kawasan. Sedangkan yang berlaku spesifik, tergantung dari daerah masing-masing yang memiliki karakteristik tersendiri.

Secara umum, sistem aturan terbagi dalam lima lingkup sistem tatanan tradisional yang mengatur pengelolaan perikanan, yakni pantang laot, adat laot, adat pemeliharaan lingkungan, adat kenduri laot, dan adat barang hanyut. Dalam kehidupan masyarakat hukom adat laot, dikenal hari-hari yang menjadi pantang melaut, antara lain: hari kenduri laot (3 hari), hari J umat (1 hari), hari raya Idul Fitri ( 3 hari), hari raya Idul Adha (3 hari), hari kemerdekaan 17 Agustus (1 hari), dan 26 Desember sebagai peringatan tsunami (1 hari). Ketika suatu kapal nelayan terjadi kerusakan di laut, maka kapal lainnya yang berada di sekitarnya harus datang dan menolong. Demikian juga bila terjadi kecelakaan di laut, seluruh kapal akan membantu dan mencari nelayan bila ada yang hilang.

Hukom adat laot melarang segala jenis alat yang bisa merusak lingkungan, seperti pemboman, peracunan, pembiusan, penyetruman, dan sebagainya. Di samping itu, larangan juga berlaku terhadap penebangan berbagai pohon di pinggir pantai seperti arun (cemara), pandan, ketapang, bakau, dan pengambilan terumbu karang. Hukom adat laot juga melarang 
pengambilan berbagai hewan dan tumbuhan yang dilindungi atau yang termasuk dalam pengawasan peneliti lingkungan. Mengenai temuan barang hanyut di laut, nelayan yang menemukan harus menyerahkan kepada Panglima Laot setempat untuk mengurus atau menyerahkan ke lembaga yang berwenang.

Terhadap berbagai kearifan tersebut, juga disusun sejumlah sanksi yang umumnya diputuskan oleh lembaga peradilan adat, yakni menyita seluruh hasil tangkapan dan diserahkan ke lembaga keagamaan, serta larangan melaut selama 3 hingga 7 hari. Berdasarkan ketentuan awal yang sudah disebutkan di bagian sebelumnya, maka kearifan tersebut adalah legal secara yuridis-formal. Dalam kajian antropologi hukum, kondisi seperti ini sesungguhnya bisa digolongkan ke dalam bentuk apa yang disebutkan Griffith sebagai pluralisme hukum yang lemah. Griffith membedakan pluralisme hukum yang lemah dengan yang kuat. Pluralisme hukum yang lemah (weak legal pluralism) adalah bentuk lain dari sentralisme hukum. Dalam hal ini hukum negara tetap dipandang sebagai superior, sedangkan hukum yang lain disatukan dalam hirarki di bawah hukum negara. ${ }^{18}$ Tak pelak, apa yang diatur dalam ola kearifan tradisional perikanan di Aceh adalah bagian dari pluralisme hukum yang lemah ini. Sementara pluralisme hukum yang kuat (strong legal pluralism) memandang fakta adanya kemaj emukan tatanan hukum yang terdapat di semua (kelompok) masyarakat. Semua sistem hukum yang dipandang sama kedudukannya dalam masyarakat, tidak terdapat hierarki yang menunjukkan sistem hukum yang satu lebih tinggi dari yang lain. Griffiths sendiri memasukkan pandangan beberapa ahli ke dalam pluralisme hukum yang

18 Pluralisme hukum merupakan konsep tanding terhadap sentralisme hukum yang menganggap hukum Negara adalah satu-satunya. Dalam konstalasi Indonesia pada masa kolonial, hukum bumi putra hanya bisa berlaku berdasarkan ketentuan kolonial. Artinya Negara memiliki otoritas penuh untuk menentukan ukuran yang disebut hukum dan memiliki kekuasaan untuk memastikan bahwa kebiasaan maupun hukum adat dapat menjadi hukum. Bernard Steny, "Pluralisme Hukum: Antara Perda Pengakuan Masyarakat Adat dan Otonomi Hukum Lokal", Jurnal Pembaruan Desa dan Agraria, III (III) 2006, hIm. 84-85 kuat, antara lain teori living law dari Eugene Ehrlich, yaitu aturan-aturan hukum yang hidup dari tatanan normatif, yang dikontraskan dengan hukum negara. ${ }^{19}$

Indonesia sendiri tidak bisa mengingkari kebhinnekaan sosial dan budaya serta kemajemukan normatif yang secara nyata hidup, dianut, dan dioperasikan masyarakat lokal di berbagai kawasan di Indonesia, terutama komunitas-komunitas masyarakat adat yang memiliki sistem hukum sendiri (self regulation) yang dikenal sebagai hukum adat. ${ }^{1920}$ Dengan kata lain, bangsa Indonesia sendiri tidak bisa dipisahkan dari nilai-nilai tradisional. Pancasila sendiri menunjukkan bahwa nilai-nilai yang hendak dijadikan dasar untuk mengatur kehidupan berbangsa dan bernegara adalah nilainilai yang terdapat, tumbuh dan berkembang pada rakyat dan masyarakat Indonesia, seperti musyawarah, gotong royong, komunalis, dan magis religius, serta menghargai kebhinnekaan (pluralisme).

Pluralisme hukum inilah yang memungkinkan adanya penghargaan terhadap hukum lokal (local law)-yang dalam istilah Simarmatabisa disamakan dengan hukum rakyat (folk law). Istilah hukum lokal sekaligus mengandung hukum adat, kebiasaan, dan hukum agama. Ada banyak istilah hukum lokal: hukum tradisional, hukum adat (customary law), hukum asli (indigenous (aw), hukum rakyat. Masalah yang muncul dengan istilah seperti "adat" dan "tradisional" adalah, bahwa istilah itu lebih menunjuk masa lalu yang seolah tidak berubah, meskipun pada kenyataannya segala jenis hukum senantiasa berubah. Bahkan di beberapa tempat perubahan sangat cepat. ${ }^{23}$

19 Brian Tamanaha, 1993, "The Folly of the Concept of Legal Pluralism", Paper The XIth International Congress of Commission on Folk Law and Legal Pluralism, New Zealand: Law Faculty, Victoria University of Wellington, p. 24-25.

20 Lihat Farida Patittingi, "Peranan Hukum Adat Dalam Pembinaan Hukum Nasional Dalam Era Globalisasi", Majalah IImu Hukum Amanna Gappa XI (13) JanuariMaret 2003, Fakultas Hukum Universitas Hasanudin, hlm. 411

23 Keebet von Benda-Beckmann, 2005, Pluralisme Hukum, Sebuah Sketsa Genealogis dan Perdebatan Teoritis, J akarta: HuMa dan Ford Foundation, hlm. 24. 
Suasana pluralisme hukum (bila kemudian kita gunakan konsep Hooker) adalah situasi khusus ketika hukum negara "mengakui" beberapa bentuk "hukum adat". ${ }^{24} \mathrm{Hal}$ demikian terlihat dalam konstitusi negara Indonesia. Dalam Pasal 18B ayat (2) UUD NRI 1945 diatur bahwa: "Negara mengakui dan menghormati kesatuankesatuan masyarakat hukum adat beserta hakhak tradisionalnya sepanjang masih hidup dan sesuai dengan perkembangan masyarakat dan prinsip Negara Kesatuan Republik Indonesia yang diatur dalam undang-undang". Kalimat dalam Pasal 18B ayat (2) UUD NRI 1945 menunjukkan betapa negara merasa memiliki sekalian kekuasaan dan kekuatan untuk menemukan apa yang terjadi di NKRI ini, termasuk apakah hukum adat masih berlaku atau tidak. Hukum adat itu beranyaman dan berkelindan kuat dengan budaya setempat. ${ }^{25}$

Berbagai macam norma yang hidup dalam komunitas, terutama sekali yang berhubungan dengan hak dan kewajiban sumberdaya alam yang mengelilingi mereka. Mereka mewarisi hal-hal tersebut dari leluhur mereka. Menurut Titahelu, mereka menganggap sumberdaya alam tidak semata-mata untuk memenuhi manfaat ekonomi ataupun sekedar memenuhi kebutuhan sehari-hari, tetapi pada saat tertentu juga mempunyai nilai budaya, spritual, sosial, politik, dan ekologis. ${ }^{26} \mathrm{Hal}$ ini dimungkinkan karena masyarakat adat memandang dirinya sebagai bagian integral dari komunitas ekologis, sarat dengan moralitas ekologis. ${ }^{27}$ Konsep inilah yang kemudian membawa pengaruh terhadap konsepsi kesejahteraan, sebagaimana diamanahkan Pasal 33 ayat (3) UUD NRI 1945, bahwa bumi, air, dan kekayaan alam yang terkandung di dalamnya dikuasai oleh negara dan dipergunakan untuk sebesar-besar kemakmuran rakyat.

24 John Griffiths, 2005, Memahami Pluralisme Hukum, Sebuah Deskripsi Konseptual,Jakarta: HuMa dan Ford Foundation, hlm. 81

25 Satjipto Rahardjo, 2006, Negara Hukum yang Membahagiakan Rakyatnya, Yogyakarta: Genta Press, hlm. 111.

26 Rikardo Simarmata, 2005, hlm. 198.

27 A. Sonny Keraf, 2002, hlm. 284.

\section{Perkembangan Pelaksanaan Kearifan Tradi- sional}

Era otonomi khusus adalah batasan dari suatu durasi waktu, dimana negara sudah menempatkan daerah pada posisi penting dalam kebangunan Negara Kesatuan Republik Indonesia. Dalam era tersebut, kewenangan untuk menjalankan pola kearifan lokal sudah terbuka lebar.

Sebelumnya, bila kita melihat perubahan konsep otonomi sebelumnya, dapat dilihat dalam beberapa Undang-Undang sebagai berikut. Pertama. Undang-Undang Nomor 1 Tahun 1945, yang mengatur mengenai pembentukan badan perwakilan rakyat daerah yang dipilih dan bersama-sama kepala daerah bertugas menjalankan pemerintahan daerah; kedua, Undang-Undang Nomor 22 Tahun 1948 menentukan batasbatas wewenang daerah, dimana ditegaskan mengenai kewenangan daerah untuk memajukan daerahnya. Dalam era ini dikenal daerah istimewa; ketiga, Undang-Undang Nomor 1 Tahun 1957, daerah diberi keleluasaan untuk mengatur rumah tangganya sendiri dan daerah istimewa.

Keempat, Undang-Undang Nomor 18 Tahun 1965, memberi harapan mengenai konsep otonomi daerah yang lebih nyata; kelima, Undang-Undang Nomor 5 Tahun 1974, mulai di kenal mengenai konsep otonomi yang nyata dan bertanggung jawab; keenam, Undang-Undang Nomor 22 Tahun 1999 yang merupakan pintu bagi konsep desentralisasi yang sebenarnya yang mulai dijalankan di Indonesia; ketujuh, Undang-Undang Nomor 32 Tahun 2004, memperbaiki beberapa konsep yang dianggap tidak sesuai dengan semangat otonomi daerah, yang dikaitkan dengan kesejahteraan rakyat; dan kedelapan, Undang-Undang Nomor 12 Tahun 2008, menambahi kekurangan yang ada dalam Undang-Undang sebelumnya, terutama berkaitan dengan perubahan-perubahan baru dalam bidang hukum dan politik yang terkait dengan pemerintahan daerah. Amandemen Undang-Undang Dasar 1945 merupakan bagian penting yang sangat berpengaruh dalam otonomi daerah itu sendiri. Da-lam masa terakhir, konsep 
kearifan lokal dalam pengelolaan perikanan benar-benar terbuka lebar.

Hukom adat laot di Aceh mendapat pengakuan dalam peraturan perundang-undangan. Masyarakat hukum adat laot diakui dalam perundang-undangan di Indonesia. Pasal 18B ayat (2) UUD 1945 menyebutkan bahwa "negara mengakui dan menghormati kesatuan-kesatuan masyarakat hukum adat beserta hak-hak tradisionalnya sepanjang masih hidup dan sesuai dengan perkembangan masyarakat dan prinsip negara kesatuan Republik Indonesia yang diatur dengan undang-undang". Di Aceh, pengakuan ini antara lain bisa dilihat dalam Peraturan Daerah Nomor 2 Tahun 1990 tentang Pembinaan dan Pengembangan Adat-istiadat, Kebiasaan Masyarakat beserta Lembaga Adat Provinsi Daerah Istimewa Aceh. Peraturan Daerah menempat hukom adat laot pada posisi adat yang dikenal dan diatur di Provinsi Daerah Istimewa Aceh.

Aceh, dalam era reformasi mendapat status khusus dengan Undang-Undang Nomor 44 Tahun 1999 tentang Penyelenggaraan Keistimewaan Aceh. Dalam undang-undang juga mengatur mengenai penyelenggaraan kehidupan adat. Sebagai tindak lanjut dari undang-undang tersebut, dibentuk Peraturan Daerah Nomor 7 Tahun 2000 tentang Penyelenggaraan Kehidupan Adat. Pada tahun 2000, Gubernur Aceh menerbitkan Surat Keputusan Nomor: 523/315/ 2000 tentang Pengukuhan Panglima Laot Aceh, sebagai lembaga yang melaksanakan hukom adat laot. Keputusan tersebut kemudian diperbarui dengan Keputusan Gubernur Provinsi Nanggroe Aceh Darussalam Nomor: 523.11/ 012/ 2005 (tertanggal 8 Maret 2005) tentang Pengukuhan Panglima Laot Aceh. Dalam keputusan tersebut disebutkan bahwa Panglima Laot merupakan bagian penting dalam rangka menyukseskan pembangunan perikanan.

Otonomi yang lebih luas kembali diberikan Pemerintah melalui Undang-undang Nomor 18 Tahun 2001 tentang Otonomi Khusus bagi Aceh dengan nama Provinsi Nanggroe Aceh Darussalam. Dalam undang-undang ini juga mengakui keberadaan hukum adat dan lembaga adat di Aceh. Kemudian dalam Pasal 11 ayat (2) Qanun Nomor 16 Tahun 2002 tentang PengeloIaan Sumberdaya Kelautan dan Perikanan juga disebutkan bahwa dalam pengelolaan sumberdaya perikanan, Pemerintah Provinsi mengakui keberadaan Lembaga Panglima Laot dan hukum adat laot yang telah ada dan eksis dalam kehidupan masyarakat nelayan di Provinsi.

Pascatsunami yang melanda Aceh dan perdamaian antara Pemerintah dan Gerakan Aceh Merdeka, lahir Undang-Undang Nomor 11 Tahun 2006 tentang Pemerintahan Aceh. Dengan undang-undang tersebut memberikan landasan hukum baru yang makin menguatkan kedudukan kearifan lokal dalam hukum nasional. Sebenarnya bila kita melihat konsep hukum terhadap kearifan lokal, dengan jelas disebutkan bahwa kenyataan kearifan lokal harus menjadi bagian atau pertimbangan dalam dalam kegiatan penangkapan ikan dan pembudidayaan ikan (Pasal 6 Undang-Undang Nomor 45 Tahun 2009 tentang Perubahan atas UndangUndang Nomor 31 Tahun 2004 tentang Perikanan; Pasal 162 ayat (2) huruf e Undang-Undang Nomor 11 Tahun 2006 tentang Pemerintahan Aceh).

Berdasarkan undang-undang terakhir, kemudian secara lebih konkret ditegaskan dalam Qanun Aceh Nomor 10 Tahun 2008 tentang Pembinaan Kehidupan Adat dan Adat-Istiadat. Dalam Pasal 10 ayat (1) huruf (f) dijelaskan bahwa pembinaan dan pengembangan kehidupan adat dan adat istiadat dapat dilakukan dengan "perlindungan hak masyarakat adat, yang meliputi tanah, rawa, hutan, laut, sungai, danau, dan hak-hak masyarakat lainnya".

Semua pengaturan dan pertimbangan yang tersebut di atas, oleh ketentuan lainnya juga diperjelas sedemikian rupa. Dalam pengaturannya, hukum adat dan/ atau kearifan lokal yang dijadikan pertimbangan dalam pengelolaan perikanan adalah yang tidak bertentangan dengan hukum nasional. Bunyi penjelasan ini kurang lebih sama dengan pengaturan dalam Pasal 3 UU Nomor 5 Tahun 1960 tentang Ketentuan Pokok Agraria. Dalam konteks hukom adat 
laot, jelas tidak bertentangan dengan hukum nasional.

Pola semacam ini sudah tepat, karena dalam sejarahnya, pengelolaan perikanan di Aceh dimulai dengan inisiatif yang muncul dari masyarakat lokal dengan menggunakan pemahaman yang mereka punya (pengetahuan lokal) dan kemudian dilembagakan dengan menggunakan sistem hukum adat, salah satunya adalah adat laot. ${ }^{28}$ Konsep tersebut merupakan konsep pengelolaan berbasis pengetahuan tradisional. ${ }^{29}$ Praktek seperti ini, bisa ditandai salah satunya adalah sudah berlangsung turun-temurun. ${ }^{30}$. Paradigma seperti ini bertransformasi, terutama dari legal centralism ke legal pluralism. ${ }^{31}$ Bentuk pengelolaan tersebut di atas, menempatkan posisi pemerintah penting. ${ }^{32}$ Posisi tersebut kemudian diimplementasikan dalam pengelolaan perikanan di Aceh dengan berusaha me; libatkan masyarakat dan lembaga adat dalam pelaksanaannya. ${ }^{33}$

\section{Kearifan Tradisional dalam Pengelolaan Per- ikanan}

Peraturan yang mengatur tentang keharusan kearifan lokal dalam pengelolaan perikanan Aceh, pada kenyataannya tidak bisa dijalankan serta-merta. Harus ada keterpaduan dengan berbagai pihak lain yang terlibat dalam pengelolaan perikanan. Dalam sistem hukum, dikenal tiga komponen yang saling terkait, yakni struktur, substansi, dan kultur. ${ }^{34}$ komponen struktur berupa kelembagaan dalam rangka

28 M. Adli Abdullah, dkk, 2006, op. cit, hlm. 18.

29 Lucky Adrianto dkk, "Adopsi Pengetahuan Lokal Dalam Pengelolaan Perikanan Di Indonesia" Paper Workshop on Customary Knowledge, Mataram, Indonesia, 2-4 Agustus 2009.

30 A. Sonny Keraf, 2002, hlm. 289.

31 Rahmat Safa'at, "Transformasi Paradigma Hukum Pengelolaan Sumberdaya Alam dalam Perspektif Global: dari Legal Centralism ke Legal Pluralism", Jurnal Hukum Progresif, Vol. 3 No. 2/ Oktober 2007, hlm. 122.

32 Victor PH Nikijuluw, 2002, Rezim Pengelolaan Sumberdaya Perikanan, Pustaka Cidesindo, J akarta.

33 Mella Ismelina FR, "Pengelolaan Sumberdaya Pesisir dan Kelautan menuju Sustainable Development", Jurnal Syiar Madani (FH Unisba), Vol. VII No. 3 November 2005, hlm. 327.

34 Lawrence M. Friedman, The Legal System; A Social Science Perspective, Russel Sage Foundation, New York, 1975, pp. 16. mendukung teraktualisasinya berbagai ketentuan perundang-undangan yang mengatur pengeIolaan berbasis kearifan tradisional. Komponen substansi merupakan ketentuan yang dibuat dan digunakan untuk megatur perilaku manusia. Komponen kultur menyangkut dengan nilainilai, sikap, dan pola perilaku warga. Budaya hukum berhubungan dengan sikap dan perilaku. Makanya dalam sistem hukum, budaya hukum menjadi faktor penentu yang penting. Cita-cita hukum, tujuan pembangunan hukum, tidak dapat dicapai dengan mengabaikan peranan dan sumbangan budaya hukum.

Gambaran di atas, dalam konteks yang lebih luas, bisa dipersandingkan dengan teori pembangunan hukum Mochtar Kusumaatmaja yang terbangun dari teori orientasi kebijaksanaan Mc. Dougal dan Laswell dan teori hukum pragmatis Pound. ${ }^{35}$ Menurut teori tersebut, hukum turut ditentukan oleh proses, ${ }^{36}$ yang dalam konteks teori tersebut, hukum dapat didayagunakan sebagai alat pembaruan dan pembangunan masyarakat. ${ }^{37}$ Namun demikian tingkat keberhasilannya belum diuji padahal perubahan sistem sentralisasi ke otonomi telah menimbulkan dampak mendasar terhadap perkembangan sistem hukum. ${ }^{38}$

Perubahan sistem tersebut kemudian diimplementasikan dalam konsep pengelolaan bersama perikanan sebagai model pengelolaan yang memadukan antara manajemen (modern) dari Pemerintah dengan manajemen tradisional dari masyarakat lokal. Proses pembentukan manajemen terpadu dapat ditempuh melalui dua langkah, yakni: pertama, pemerintah secara formal mengakui peraturan informal yang hidup di tengah masyarakat, baik secara tradisional sudah ada maupun yang baru dibentuk oleh

35 Mochtar Kusumaatmadja, 1986, Hukum, Masyarakat, dan Pembinaan Hukum Nasional, Bandung: Binacipta, hlm. 5 - 10

36 Mochtar Kusumaatmadja, 1986, Pembinaan Hukum Dalam Rangka Pembangunan Nasional, Bandung: Binacipta, hlm. 11.

37 Mochtar Kusumaatmadja2000, Konsep-Konsep Hukum dalam Pembangunan, Bandung: Alumni, hlm 13 dan hlm. 74.

38 Romli Atmasasmita, 2003, Menata Kembali Masa Depan Pembangunan Hukum Nasional, Majalah Hukum Nasional No 1/ 2003, Jakarta: BPHN, hlm 1. 
masyarakat (neo-tradisional); kedua, pemerintah menyerahkan sebagian wewenangnya kepada masyarakat dalam penegakan aturan yang dibuat oleh Pemerintah. ${ }^{39}$

Pengelolaan bersama perikanan tersebut, pada akhirnya bertujuan untuk menghindari lahirnya "tragedi bersama". "Tragedi bersama" (tragedy of commons) adalah istilah yang muncul dari sebuah artikel yang dimuat di Jounal Sciences, Edisi 162: 1243-48 tahun 1968, "The Tragedy of the Commons". Teori ini dimulai dari peringatan seorang pakar biologi pada tahun 1968, Garret Hardin, tentang "akan terjadinya dalam pemanfaatan sumberdaya alam yang dimanfaatkan bersama - common-pool resources (CPRs), seperti fishing ground, ekosistem terumbu karang, teluk, danau, hutan, air tanah, dan sebagainya." Oleh Ostrom kemudian dikemukakan dua persoalan penting CPRs, Pertama, pengambilan seseorang atas resource unit (RU) dari CPRs bersifat mengurangi peluang orang lain untuk mengambil RU yang sama. Kedua, kesulitan mengontrol akses atas CPRs tersebut. Artinya, seseorang mengalami kesulitan untuk membatasi akses orang lain atas CPRs itu. ${ }^{40}$

Sebenarnya dalam pengelolaan perikanan dikenal dua bentuk regulasi. Pertama, open access adalah regulasi yang membiarkan nelayan menangkap ikan dan mengeksploitasi sumberdaya hayati lainnya kapan saja, di mana saja, berapa pun jumlahnya, dan dengan alat apa saja. Regulasi ini mirip "hukum rimba" dan "pasar bebas". Regulasi inilah yang berpotensi tragedy of commons baik berupa kerusakan sumberdaya kelautan dan perikanan maupun konflik antarnelayan. Kedua, controlled access regulation adalah regulasi terkontrol yang dapat berupa (1) pembatasan input (input restriction), yakni membatasi jumlah pelaku, jumlah jenis kapal, dan jenis alat tangkap, (2) pembatasan output (output restriction), yakni mem-

39 Sudirman Saad, "Pluralisme Hukum dan Masalah Lingkungan: Kasus Penangkapan Ikan di Danau Tempe, Sulawesi Selatan", dalam EKM Masinambow, 2003, Hukum dan Kemajemukan Budaya, Jakarta: Yayasan Obor Indonesia, hlm. 195.

40 Aceng Hidayat, "Tragedi Bersama Perikanan Indonesia", Sinar Harapan, 16 Februari 2008). batasi jumlah tangkapan bagi setiap pelaku berdasarkan kuota. Salah satu formulasi dari pembatas input itu adalah territorial use right yang menekankan penggunaan fishing right (hak memanfaatkan sumberdaya perikanan) dalam suatu wilayah tertentu dalam yurisdiksi yang jelas. Pola fishing right system ini menempatkan fishing right yang berhak melakukan kegiatan perikanan di suatu wilayah, sementara yang tidak memiliki fishing right tidak diizinkan beroperasi di wilayah itu. Selain diatur siapa yang berhak melakukan kegiatan perikanan, juga diatur kapan dan dengan alat apa kegiatan perikanan dilakukan. Sistem yang menjurus pada bentuk pengkaplingan laut ini menempatkan perlindungan kepentingan nelayan kecil yang beroperasi di wilayah pantaipesisir serta kepentingan kelestarian fungsi sumberdaya sebagai fokus perhatian. ${ }^{41}$

Berdasarkan referensi tersebut, kemudian pengelolaan bersama perikanan berusaha mengkombinasi tipe rejim kepemilikan sumberdaya oleh pemerintah dan masyarakat. Bagaimana pun, manajemen pengelolaan bersama dibutuhkan. Konsep sebagaimana disebutkan di atas, pada kenyataannya sudah berjalan di empat kabupaten pesisir pantai barat, yaitu yaitu Aceh Besar (Kawasan Bina Bahari di Lampuuk), Aceh Jaya (Kawasan Ramah Lingkungan di Lhok Rigaih dan Kawasan Peudhiet Laot di Meureuhom Daya), Aceh Barat (Kawasan Peujroh Laot di Meureubo dan Langgong), dan Nagan Raya (Kawasan Beujroh Laot di Lhok Kuala Trang, Ihok Kuala Tadu, Lhok Kuala Tripa, Ihok Babah Lueng dan Ihok Kuala Seumanyam). Hingga saat ini, komponen ini telah bekerja dalam meningkatkan pemahaman tentang pelestarian perikanan melalui pengelolaan bersama kepada para stakeholders yang terdiri dari masyarakat pesisir, panglima laot, dan pemerintah.

Namun demikian ada satu hal yang harus diingatkan, bahwa model pengelolaan bersama perikanan bukan sebagai ruang untuk menghancurkan kehidupan adat. Proses ini tidak boleh

41 Anonimious, 2007, Dokumen Analisis Kebijakan Pengelolaan Sumberdaya Kelautan dan Perikanan Provinsi Nanggroe Aceh Darussalam, Banda Aceh: WI, WWF, Both Ends, IUCN, dan Oxfam, hlm. 7. 
menghancurkan berbagai akivitas adat laot yang berlangsung, misalnya pemberian sanksi dalam pengelolaan bersama, tidak boleh menisbikan ada kearifan dalam peradilan adat di laot di wilayah pesisir.

\section{Penutup \\ Simpulan}

Berdasarkan bahasan tersebut di atas, ada beberapa simpulan penting. Pertama, daIam masyarakat Aceh, pola kearifan tradisional dalam pengelolaan perikanan dikenal dengan istilah hukom adat laot, yang berlaku dalam masyarakat yang mendiami 147 Lhok di seluruh Aceh. Masyarakat hukom adat laot memiliki kearifan dalam lima lingkup tatanan tradisional, yakni pantang laot, adat laot, adat pemeliharaan lingkungan, adat kenduri laot, dan adat barang hanyut. Kedua, konsep masyarakat hukum adat laot merupaan konsep trandisional yang dalam negara dengan pengertian modern juga diakui dengan peraturan perundang-undangan. Dalam hal ini, negara mengakui dan menghormati kesatuan masyarakat hukum adat laot dan hak tradisionalnya karena masih hidup dan berkembang dalam masyarakat. Ketiga, konsep kearifan lokal, dalam era otonomi daerah mendapat mendapat posisi penting dalam pengelolaan perikanan di Indonesia. Namun demikian, tarik-menarik kepentingan tetap terjadi, antara lain dengan membedakan konsep kearifan dengan pembangunan pada umumnya.

\section{Rekomendasi}

Pengambil kebijakan dalam rangka pelaksanaan kearifan tradisional, tidak hanya terpaku pada landasan yuridis-formal semata. Pengambil kebijakan yang mementingkan landasan yuridis-formal, seyogianya menjadikan kearifan tradisional sebagai bahan baku yang penting dalam rangka penyusunan berbagai peraturan perundang-undangan yang terkait. Di samping itu, sudah seyogianya pola pemecahan masalah tertentu melalui pendekatan yang holistik.

\section{Daftar Pustaka}

Adrianto, Lucky dkk. Adopsi Pengetahuan Lokal Dalam Pengelolaan Perikanan Di Indonesia. Paper Workshop on Customary Knowledge, Mataram, Indonesia, 2-4 Agustus 2009;

Anonimious. 2007. Dokumen Analisis Kebijakan Pengelolaan Sumberdaya Kelautan dan Perikanan Provinsi Nanggroe Aceh Darussalam. Banda Aceh: WI, WWF, Both Ends, IUCN, dan Oxfam;

AR, Razali. 2009. Profil Perikanan Tangkap Aceh. Banda Aceh: Dinas Kelautan dan Perikanan Aceh;

Atmasasmita, Romli. 2003. "Menata Kembali Masa Depan Pembangunan Hukum Nasional". Majalah Hukum Nasional No 1/ 2003. J akarta: BPHN;

Benda-Beckmann, Keebet von. 2005. Pluralisme Hukum, Sebuah Sketsa Genealogis dan Perdebatan Teoritis. Jakarta: HuMa dan Ford Foundation;

FR, Mella Ismelina. "Pengelolaan Sumberdaya Pesisir dan Kelautan menuju Sustainable Development". J urnal Syiar Madani, Vol. VII No. 3 November 2005;

Friedman, Lawrence M. 1975. The Legal System; A Social Science Perspective. New York: Russel Sage Foundation;

Griffiths, John. 2005. Memahami Pluralisme Hukum, Sebuah Deskripsi Konseptual. J akarta: HuMa dan Ford Foundation;

Hidayat, Aceng. "Tragedi Bersama Perikanan Indonesia", Sinar Harapan, 16 Februari 2008;

Kurien, J ohn. 2009. Suara Panglima Laot. Banda Aceh: FAO;

Kusumaatmadja, Mochtar. 1986. Hukum, Masyarakat, dan Pembinaan Hukum Nasional. Bandung: Binacipta;

1986. Pembinaan Hukum Dalam Rangka Pembangunan Nasional. Bandung: Binacipta;

2000. Konsep-Konsep Hukum dalam Pembangunan. Bandung: Alumni;

Masinambow, EKM. 2003. Hukum dan Kemajemukan Budaya. Jakarta: Yayasan Obor Indonesia;

Nikijuluw, Victor PH. 2002. Rezim Pengelolaan Sumberdaya Perikanan. Jakarta: Pustaka Cidesindo;

Nurjaya, I Nyoman. "Kearifan Lokal dan PengeIolaan Sumberdaya Alam". J urnal IImiah 
Vol. VIII No. 40 2007, http:// www.akhirnyaterbitjuga.com, diakses tanggal 30 November 2010;

-.-.-.-. "Pembangunan Hukum Negara dalam Masyarakat Multikultural, Perspektif Hukum Progresif". Jurnal Hukum Progresif Vol. 3 No. 2 Oktober 2007;

Patittingi, Farida. "Peranan Hukum Adat Dalam Pembinaan Hukum Nasional Dalam Era Globalisasi". Majalah IImu Hukum Amanna Gappa Vol. XI No. 13 Januari-Maret 2003, FH UNHAS;

Rahardjo, Satjipto. 2006. Negara Hukum yang Membahagiakan Rakyatnya. Yogyakarta: Genta Press;

Safa' at, Rahmat. "Transformasi Paradigma Hukum Pengelolaan Sumberdaya Alam daIam Perspektif Global: dari Legal Centralism ke Legal Pluralism". Jurnal Hukum Progresif, Vol. 3 No. 2/ Oktober 2007;

Steny, Bernard. "Pluralisme Hukum: Antara Perda Pengakuan Masyarakat Adat dan Otonomi Hukum Lokal". Jurnal Pem- baruan Desa dan Agraria, Vol. 3 No. 3 2006;

Sulaiman, "Pelaksanaan Hukom Adat Laot dalam Pengelolaan Perikanan di Aceh", J urnal Mondial IImu-IImu Sosial dan Kemasyarakatan Vol. 11 No.19 Januari-J uni 2009, Universitas Syiah Kuala Aceh;

------. "Model Pengelolaan Perikanan Berbasis Hukum Adat Laot Di Lhok Rigaih Kabupaten Aceh Jaya". J urnal Masalah-masalah Hukum No. 71 Maret 2011;

2010. Konsep Pengelolaan Sumberdaya Perikanan Berbasis Kearifan Lokal Di Aceh Pada Masa Otonomi Daerah. Makalah Lokakarya 8 Tahun Otonomi Daerah, Malang: Universitas Brawijaya;

Tamanaha, Brian. 1993. The Folly of the Concept of Legal Pluralism. Paper The XIth International Congress of Commission on Folk Law and Legal Pluralism, New Zealand: Law Faculty, Victoria University of Wellington. 